\title{
Enhanced tropospheric BrO over Antarctic sea ice in mid winter observed by MAX-DOAS on board the research vessel Polarstern
}

\author{
T. Wagner ${ }^{1}$, O. Ibrahim ${ }^{2}$, R. Sinreich ${ }^{2}$, U. Frieß ${ }^{2}$, R. von Glasow ${ }^{3}$, and U. Platt ${ }^{2}$ \\ ${ }^{1}$ Max-Planck-Institute for Chemistry, Mainz, Germany \\ ${ }^{2}$ Institut für Umweltphysik, University of Heidelberg, Heidelberg, Germany \\ ${ }^{3}$ School of Environmental Sciences, University of East Anglia, Norwich, UK
}

Received: 8 January 2007 - Published in Atmos. Chem. Phys. Discuss.: 5 February 2007

Revised: 14 May 2007 - Accepted: 6 June 2007 - Published: 19 June 2007

\begin{abstract}
We present Multi AXis-Differential Optical Absorption Spectroscopy (MAX-DOAS) observations of tropospheric BrO carried out on board the German research vessel Polarstern during the Antarctic winter 2006. Polarstern entered the area of first year sea ice around Antarctica on 24 June 2006 and stayed within this area until 15 August 2006. For the period when the ship cruised inside the first year sea ice belt, enhanced $\mathrm{BrO}$ concentrations were almost continuously observed. Outside the first year sea ice belt, typically low $\mathrm{BrO}$ concentrations were found. Based on back trajectory calculations we find a positive correlation between the observed $\mathrm{BrO}$ differential slant column densities $(\triangle \mathrm{SCDs})$ and the duration for which the air masses had been in contact with the sea ice surface prior to the measurement. While we can not completely rule out that in several cases the highest $\mathrm{BrO}$ concentrations might be located close to the ground, our observations indicate that the maximum $\mathrm{BrO}$ concentrations might typically exist in a (possibly extended) layer around the upper edge of the boundary layer. Besides the effect of a decreasing $\mathrm{pH}$ of sea salt aerosol with altitude and therefore an increase of $\mathrm{BrO}$ with height, this finding might be also related to vertical mixing of air from the free troposphere with the boundary layer, probably caused by convection over the warm ocean surface at polynyas and cracks in the ice. Strong vertical gradients of $\mathrm{BrO}$ and $\mathrm{O}_{3}$ could also explain why we found enhanced $\mathrm{BrO}$ levels almost continuously for the observations within the sea ice. Based on our estimated $\mathrm{BrO}$ profiles we derive $\mathrm{BrO}$ mixing ratios of several ten ppt, which is slightly higher than many existing observations. Our observations indicate that enhanced $\mathrm{BrO}$ concentrations around Antarctica exist about one month earlier than observed by satellite instruments. From detailed radiative transfer simulations we find that MAX-DOAS observations are up to about one order of magnitude more sensitive to near-surface
\end{abstract}

Correspondence to: T. Wagner

(thomas.wagner@mpch-mainz.mpg.de)
BrO than satellite observations. In contrast to satellite observations the MAX-DOAS sensitivity hardly decreases for large solar zenith angles and is almost independent from the ground albedo. Thus this technique is very well suited for observations in polar regions close to the solar terminator. For large periods of our measurements the solar elevation was very low or even below the horizon. For such conditions, most reactive $\mathrm{Br}$-compounds might exist as $\mathrm{Br}_{2}$ molecules and ozone destruction and the removal of reactive bromine compounds might be substantially reduced.

\section{Introduction}

During the 1980's it was discovered that in the polar spring's troposphere the ozone concentrations occasionally drop below the detection limit (Bottenheim et al., 1986; Oltmans and Komhyr, 1986; Solberg et al., 1996). Typically, low ozone values were observed for periods of several hours to several days and the phenomenon was termed 'troposheric ozone hole'. Only a few years later, Barrie et al. (1988) discovered that enhanced concentrations of tropospheric bromine compounds are very likely the cause for the very efficient ozone destruction. Later on, it was shown by several groups that in particular enhanced $\mathrm{BrO}$ concentrations are present during such episodes of tropospheric ozone depletion (Hausmann and Platt, 1994; Platt and Lehrer, 1996; Kreher et al., 1997; Tuckermann et al., 1997; Hönninger and Platt, 2002). A short summary of the relevant chemical reactions is given in Sect. 2.

After the launch of the Global Ozone Monitoring Experiment (GOME) aboard the European research satellite ERS2 , it became possible for the first time to search the whole globe for enhanced tropospheric $\mathrm{BrO}$ concentrations and it was found that enhanced boundary layer $\mathrm{BrO}$ concentrations were indeed present over large areas in both polar regions during spring (Wagner and Platt, 1998; Richter et al., 1998,

Published by Copernicus Publications on behalf of the European Geosciences Union. 
2002; Wagner et al., 2001; Hollwedel et al., 2003; Jacobi et al., 2006). From these satellite observations also indications were found for a strong relation to the presence of first year sea ice (Wagner et al., 2001) and to areas potentially covered by so called frost flowers (Kaleschke et al., 2004). Today, still uncertainties exist on the detailed release mechanisms of the reactive bromine compounds (see e.g. Sander et al., 2006, and references therein; Simpson et al., 2007a). In particular also the importance of different potential sources enriched in bromide is unclear: such sources could be provided e.g. by frost flowers, snow flakes fallen into enriched brine; aerosols enriched in bromide can be created by wind gusts on these surfaces, on the brine itself (Sander et al., 2006) or by other processes (Domine et al., 2004; Simpson et al., 2005, 2007b).

Besides the satellite observations, only few ground based measurements have so far been carried out in regions where the enhanced boundary layer $\mathrm{BrO}$ concentrations actually appear, e.g. at Barrow, Alert, Hudson Bay in Canada, or Ny Alesund at Spitsbergen (Hausmann and Platt, 1994; Tuckermann et al., 1997; Hönninger and Platt, 2002; Hönninger et al., 2004a, b; Simpson et al., 2005, 2007b). Especially in Antarctica and/or within areas of first year sea ice such observations are sparse (e.g. Kreher et al., 1997; Frieß et al., 2004). Thus, and because of several limitations of the satellite observations, still many open questions remain, not only on the details of the related chemistry (see e.g. Sander et al., 2006) but also on the characteristic circumstances necessary for the occurrence of enhanced $\mathrm{BrO}$ concentrations (see Simpson et al., 2007b, for an overview of our current knowledge).

In particular, it is unclear when and under which conditions the enhanced boundary layer $\mathrm{BrO}$ concentrations first appear in polar spring. From satellite observations the first events are typically found in mid January (Arctic) and at the end of July (Antarctica) (Wagner et al., 2001). However, satellite observations of boundary layer $\mathrm{BrO}$ are only possible if the sun is clearly above the horizon. For measurements at solar zenith angles (SZA) larger than about $87^{\circ}$, the sensitivity towards boundary layer $\mathrm{BrO}$ strongly decreases while that for stratospheric BrO strongly increases (Wagner et al., 2001) (see also Sect. 4.2). This dependence on the solar elevation prevents the unambiguous detection of enhanced boundary layer $\mathrm{BrO}$ concentrations for the period directly after the end of the polar night.

Another important question concerns the spatial homogeneity and extension of the air masses of enhanced $\mathrm{BrO}$ concentrations. The areas of enhanced $\mathrm{BrO}$ concentrations can have dimensions of up to thousands of kilometres which can well be observed by satellite instruments. However, the ground pixel size of satellite observations is still too large to resolve gradients on scales of only kilometres. Thus air masses of enhanced $\mathrm{BrO}$ concentrations with smaller dimensions are difficult to observe. Similarly, also small air masses without enhanced $\mathrm{BrO}$ concentrations in regions with otherwise enhanced $\mathrm{BrO}$ might be overlooked. In general, it is not possible to directly retrieve information about spatial gradients on scales with smaller dimension than the ground pixel size of satellite observations. Another limitation of the satellite observations is that in many cases enhanced $\mathrm{BrO}$ concentrations might be at least partly shielded by clouds. Thus, in some situations, when no enhanced BrO concentrations are observed by satellite, it remains unclear if actually no enhanced $\mathrm{BrO}$ concentrations exist or if they are simply shielded by clouds.

Finally, it is not clear, how far the air masses with enhanced $\mathrm{BrO}$ concentrations can be transported away from their source regions. Strongly enhanced BrO concentrations have so far mainly been observed over areas of first year sea ice or very close to them (e.g. Wagner et al., 2001; Frieß et al., 2004; Kaleschke et al., 2004). In particular, it is unclear how far air masses of enhanced $\mathrm{BrO}$ concentrations might be transported over the open ocean. From satellite observations over the open ocean typically no enhanced BrO concentrations are detected (with very few exceptions). Because of the low surface albedo of the ocean surface the sensitivity of the satellite observations is strongly reduced compared to observations over snow and ice (see Sect. 4.2). Thus, especially for observations over oceanic regions close to the edge of the sea ice it remains unclear if actually no enhanced $\mathrm{BrO}$ concentrations exist or if they are just not "seen" by the satellite instrument.

Here we present Multi AXis-Differential Optical Absorption Spectroscopy (MAX-DOAS) observations made on the research vessel Polarstern during austral winter 2006 (details on the cruise can be found at the Polarstern web-page of the Alfred-Wegener Institute: http://www.awi-bremerhaven.de/ Polar/polarstern.html). From these observations new information on the above mentioned open questions could be derived. The main advantage of these measurements is that they were performed on board of an ice breaker, which directly crossed the areas of first year sea ice. MAX-DOAS observations are performed in various slant viewing directions, which make them especially sensitive to tropospheric trace gases (Leser et al., 2003; Van Roozendael et al., 2003; Wittrock et al., 2003; Hönninger et al., 2004a, b; Wagner et al., 2004; Sinreich et al., 2005; Heckel et al., 2005; Frieß et al., 2006; Wagner et al., 2007). One specific advantage of MAX-DOAS observations is that they remain sensitive to boundary layer BrO concentrations even for large SZA (see Sect. 4.2), thus enabling measurements directly after the end of the polar night. Finally, the sensitivity of MAX-DOAS observations is very similar over areas of high albedo (snow and ice) and low albedo (ocean). Thus, in contrast to satellite observations, low BrO $\triangle$ SCDs measured by MAXDOAS unambiguously indicate low boundary layer BrO concentrations over the open ocean. 


\section{Bromine chemistry during polar winter}

The most important reaction paths for $\mathrm{Br}$ chemistry under polar conditions are summarised in Fig. 1. Ozone destruction occurs via the following sequence: reaction of $\mathrm{Br}$ with $\mathrm{O}_{3}$ to $\mathrm{BrO}$, (typical time constant about $1 \mathrm{~s}$ ), $\mathrm{BrO}$ is converted back to $\mathrm{Br}$ via various path ways e.g. $\mathrm{BrO}$ self reaction, closing the catalytic ozone destruction cycle (note that $\mathrm{BrO}$ photolysis does not lead to $\mathrm{O}_{3}$ destruction). Removal of reactive $\mathrm{Br}$ compounds occurs via reaction with $\mathrm{HO}_{2}, \mathrm{HCHO}$ and olefins with a typical time constant of the order of $100 \mathrm{~s}$. Efficient ozone destruction only occurs, if recycling mechanisms compensate this loss of reactive Br-compounds. Such recycling can occur via heterogeneous reactions (of e.g. $\mathrm{HOBr}$ with $\left.\mathrm{Br}^{-}\right)$on ice or snow covered surfaces enriched in sea salt and/or on aerosol particles containing $\mathrm{Br}^{-}$(e.g. sea salt).

Under conditions of high sun (sun elevation $\gtrsim 10^{\circ}$ ) during polar spring, photolysis of $\mathrm{BrO}$ shifts the partitioning between $\mathrm{BrO}$ and $\mathrm{Br}$ towards $\mathrm{Br}(\mathrm{Br} / \mathrm{BrO} \approx 0.01)$. For high $\mathrm{BrO}$ concentrations, the $\mathrm{BrO}$ self reaction strengthens this shift towards $\mathrm{Br}$.

Under conditions of low sun, in particular for sun elevation angles close or even below the horizon, the photolysis rates substantially decrease. As a consequence, $\mathrm{Br}$ levels drop. At elevated $\mathrm{BrO}$ concentrations ( $>$ few ppt), $\mathrm{BrO}$ can still be converted to $\mathrm{Br}$ via its self reaction. However, since the product yield is about $20 \%$ for $\mathrm{Br}_{2}$ and $80 \%$ for $2 \mathrm{Br}, \mathrm{Br}_{2}$ molecules will accumulate. This conversion of $\mathrm{BrO}$ into $\mathrm{Br}_{2}$ can also occur via reaction with $\mathrm{HO}_{2}$ into $\mathrm{HOBr}$ and subsequent heterogeneous reaction to $\mathrm{Br}_{2}$. We conclude that under conditions with low sun elevation (and low DMS concentrations as to be expected over areas of sea ice), most reactive $\mathrm{Br}$-compounds will exist as $\mathrm{Br}_{2}$ molecules. As a consequence, ozone destruction and the removal of reactive compounds due to reaction of $\mathrm{BrO}$ with $\mathrm{HO}_{2}, \mathrm{HCHO}$ and olefins will be substantially reduced. Note that these considerations indicate only the general dependencies; the actual partitioning for a given situation (characterised by a specific solar zenith angle and specific change of solar zenith angle with time) requires more detailed modelling studies.

\section{Ship cruise and instrumental set-up}

The MAX-DOAS instrument was installed on board the research vessel Polarstern in October 2005 and since then continuously performed automatic measurements during the entire cruise (see also cruise information at: http://www. awi-bremerhaven.de/Polar/polarstern.html). In austral winter 2006, Polarstern penetrated into the first year sea ice area which surrounds the Antarctic continent; the first contact was on 24 June 2006 at $59.5^{\circ} \mathrm{S}, 5.0^{\circ} \mathrm{E}$. On its way back, Polarstern left the sea ice belt on 15 August 2006 at about $55.5^{\circ} \mathrm{S}, 3^{\circ} \mathrm{E}$. The sea ice in the area which Polarstern crossed was almost exclusively first year sea ice, containing cracks,

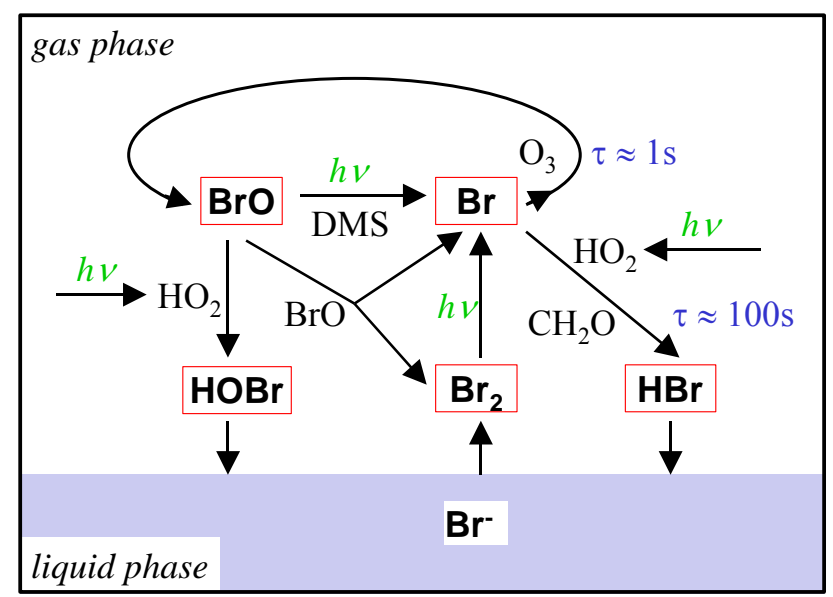

Fig. 1. Overview on the most important reaction paths for $\mathrm{Br}-$ chemistry under polar conditions. The liquid phase represents snow and ice covered surfaces enriched in sea ice and/or aerosol particles.

polynyas and areas with Nilas and young ice (L. Kaleschke, personal communication).

During the whole path within the sea ice belt, the solar zenith angle was rather large. At the beginning, the daily minimum values were around $80^{\circ}$; from 3 July 2006 to 7 July 2006 they stayed $>90^{\circ}$; after 14 August 2006 they reached values $<70^{\circ}$. Even on the days with large SZA, successful MAX-DOAS measurements of enhanced tropospheric $\mathrm{BrO}$ were possible (except for five days at the beginning of July).

The MAX-DOAS instrument consists of an indoor and an outdoor set-up. Both are connected via electric cables and quartz fibres. The telescope is mounted in a small heated box, which is moved by a stepper motor to allow elevation angles $(\alpha)$ between $0^{\circ}$ (pointing to the horizon) and $90^{\circ}$ (pointing to the zenith); the sequence of elevation angles is $1^{\circ}$, $3^{\circ}, 6^{\circ}, 10^{\circ}, 30^{\circ}, 90^{\circ}$. The telescope box itself is mounted on a large gimbal-mounted damped pendulum with a heavy lead weight, to minimise the influence of the ship movement. From the geometry of the telescope and the quartz fibre, the field of view is determined as about 1.1 degree. The adjustment of the elevation angles is performed using a water level; the accuracy is estimated to be about 0.5 degree. It should be noted that due to possible ice layers on the telescope and/or the ship movement, the actual field of view might be substantially larger for individual observations. Unfortunately, so far it was not possible to quantify and monitor these effects in detail. Nevertheless, it is important to note that from the measured radiances and $\mathrm{O}_{4}$ absorptions we found no indications for a substantial and continuous deviation from the stated values of the field of view and the elevation angle. In particular there is no evidence that the field of view for the lowest elevation angle hits the ground.

The light is fed into an Ocean Optics USB 2000 spectrograph that disperses the light with a grating and maps it 
onto a one dimensional CCD array with 2048 elements. The wavelength range reaches from $290 \mathrm{~nm}$ to $430 \mathrm{~nm}$, thus enabling the analysis of various trace gases including e.g. $\mathrm{O}_{3}$, $\mathrm{NO}_{2}, \mathrm{BrO}, \mathrm{OClO}, \mathrm{HCHO}$, and $\mathrm{SO}_{2}$. The spectral resolution is about $0.9 \mathrm{~nm}$ (full width at half maximum).

The spectrometer is mounted into a modified hermetic Dewar vessel. In order to avoid ambient air from penetrating into the protective vessel it had been evacuated and filled up with gaseous Argon up to 1.2 bar prior to the expedition. Stable measurement conditions and low detector noise could be achieved by cooling the spectrograph down to approx. $0^{\circ} \mathrm{C}$ by a two-stage Peltier cooling unit. Spectra are taken about every 2 minutes between sunrise and sunset. During the night (for SZA $>97^{\circ}$ ) automatic measurements of offset and dark current are taken. The correct time (UTC) and position of the ship is provided from the on board computer system.

\section{Data analysis}

\subsection{Spectral retrieval}

The measured spectra are analysed using the DOAS method (Platt, 1994). To the (logarithm of the) measured spectrum several trace gas cross sections as well as a Ring spectrum (Grainger and Ring, 1962), a Fraunhofer reference spectrum and a polynomial of low degree are fitted by means of a least squares fitting routine (Stutz and Platt, 1996). To extract the tropospheric absorptions from the measured spectra (taken at low elevation angles), the Fraunhofer spectrum was always taken from the directly preceding zenith observation. For the $\mathrm{BrO}$ analysis, the wavelength range $335.3-358.9 \mathrm{~nm}$ was used and the cross sections of ozone (223 and $243 \mathrm{~K}$, Bogumil et al., 2003), $\mathrm{NO}_{2}(220 \mathrm{~K}$, Vandaele et al., 1997), $\mathrm{BrO}$ (Wilmouth et al., 1999), and the oxygen dimer $\mathrm{O}_{4}$ (Greenblatt et al., 1990) were included. The Ring spectrum was calculated from a measured spectrum. For the $\mathrm{O}_{4}$ analysis the wavelength range $345.0-364.5 \mathrm{~nm}$ was used and the cross sections of ozone $(223 \mathrm{~K}), \mathrm{NO}_{2}, \mathrm{BrO}$, and $\mathrm{O}_{4}$ were included. The wavelength calibration was performed by fitting the measured spectra to a high resolution solar spectrum (Kurucz et al., 1984). From the spectral analysis the so called slant column density (SCD) is retrieved, which is the integrated trace gas concentration along the light path through the atmosphere.

Because the Fraunhofer spectrum also contains atmospheric absorption structures of the atmospheric trace gases, the result of the DOAS analysis represents the difference of the SCDs of the measured spectrum and of the Fraunhofer spectrum. In the following we will refer to them as differential slant column densities $\left(\triangle \mathrm{SCD}=\mathrm{SCD}_{\text {meas }}-\mathrm{SCD}_{\text {ref }}\right)$. Since the Fraunhofer spectrum was measured in zenith direction, the respective tropospheric absorptions are typically very weak compared to those measured at low elevation angles. Thus the measured $\triangle \mathrm{SCD}$ is roughly proportional to the tropospheric concentration. For the detailed interpretation of the retrieved $\triangle \mathrm{SCD}$ radiative transfer modelling has to be applied.

\subsection{Radiative transfer modelling}

In this section we present results of radiative transfer modeling using our Monte Carlo model "TRACY-2" (Deutschmann and Wagner, 2006; Wagner et al., 2007), which takes into account multiple scattering, and full sphericity. From our model results we can estimate the sensitivity of the MAX-DOAS observations for boundary layer $\mathrm{BrO}$ under different measurement conditions. Usually the results of radiative transfer modelling are expressed as air mass factors (AMF), which represent the ratio between the slant column density (SCD) and the vertical column density (VCD) (Noxon et al., 1979; Solomon et al., 1987; Marquard et al., 2000).

$\mathrm{AMF}=\mathrm{SCD} / \mathrm{VCD}$

The AMF can be seen as an indicator for the sensitivity of the observation. The AMF of MAX-DOAS observations of tropospheric species can reach especially large values $(A M F>30)$. Since the results of the MAX-DOAS observations are expressed as $\triangle \mathrm{SCD}$, we also calculate so called "differential AMF" $\left(\triangle \operatorname{AMF}(\alpha)=\operatorname{AMF}(\alpha)-\operatorname{AMF}\left(90^{\circ}\right)\right)$ by subtracting the modelled AMF for the zenith direction (elevation angle $\alpha=90^{\circ}$ ) from the modelled AMFs for the low elevation angles $(\alpha)$. The VCDs can then be derived by dividing the measured $\triangle \mathrm{SCD}$ by the appropriate $\triangle \mathrm{AMF}$.

$\mathrm{VCD}=\frac{\Delta \mathrm{SCD}}{\Delta \mathrm{AMF}}=\frac{\operatorname{SCD}(\alpha)-\operatorname{SCD}\left(90^{\circ}\right)}{\operatorname{AMF}(\alpha)-\operatorname{AMF}\left(90^{\circ}\right)}$

It should be noted that the AMF for the zenith direction is usually close to unity; thus especially for the large AMFs at low elevation angles the $\triangle \mathrm{AMF}$ can be approximated by the AMF.

The sensitivity (the $\triangle \mathrm{AMF}$ ) of MAX-DOAS observation strongly depends on the atmospheric visibility (Wagner et al., 2004, 2007; Heckel et al., 2005; Frieß et al., 2006). In the presence of aerosols or clouds, the sensitivity can be strongly reduced. Especially in the case of fog, the atmospheric absorption paths for all viewing directions (including the zenith direction) can become very similar; consequently for such cases the $\triangle \mathrm{SCDs}$ and $\triangle \mathrm{AMFs}$ become zero.

To estimate the atmospheric visibility we investigated the simultaneously observed absorptions of $\mathrm{O}_{4}$. Since the oxygen content of the atmosphere varies only slightly (due to temperature and pressure variations), the variations of the observed $\mathrm{O}_{4} \Delta \mathrm{SCD}$ can be used as an indicator for variations of the atmospheric radiative transfer. Especially situations with a poor visibility, e.g. due to fog, can be identified by low $\mathrm{O}_{4}$ $\triangle$ SCDs.

In the following examples we investigate the sensitivity of MAX-DOAS observations to surface near BrO concentrations and the $\mathrm{O}_{4}$ absorption. Our particular interest is the 
dependence of the sensitivity on the atmospheric visibility and the surface albedo.

In our first modelling case study we simulate the atmospheric radiative transfer at $350 \mathrm{~nm}$ for the different elevation angles $\left(1^{\circ}, 3^{\circ}, 6^{\circ}, 10^{\circ}, 30^{\circ}, 90^{\circ}\right)$ for various atmospheric aerosol loads. We calculate $\triangle \mathrm{AMFs}$ for different height profiles assuming a surface albedo of $80 \%$. Here it should be noted that the albedo of snow can vary substantially, depending especially on its age. In particular for fresh snow the albedo can even be higher than $80 \%$ (Warren, 1982). Nevertheless, for high values of the surface albedo the relative influence of changes of the albedo are much smaller than for low surface albedos. Thus the AMFs calculated for an albedo of $80 \%$ can be regarded as representative for a wide range of snow covered surfaces.

For the calculation of $\triangle \mathrm{AMF}$ we assumed five different profile shapes. While in reality the vertical distribution of the $\mathrm{BrO}$ concentration might have a more complex shape, the selected profiles can give insight in the overall dependency of the sensitivity on altitude.

The first four profiles describe constant $\mathrm{BrO}$ concentrations within different height layers: $\mathrm{BrO}-1$ : 0-200 m, BrO2: $200-400 \mathrm{~m}, \mathrm{BrO}-3:$ : $00-1000 \mathrm{~m}, \mathrm{BrO}-4:$ 0-1000 m (note that very similar results are obtained if constant mixing ratios are assumed). The fifth profile has the relative shape of the atmospheric $\mathrm{O}_{4}$ profile (proportional to the quadratic $\mathrm{O}_{2}$ concentration, see e.g. Greenblatt et al., 1990). For clear sky (Fig. 2a) the $\triangle$ AMFs strongly increase with decreasing elevation angle. Especially for the surface-near profile (BrO-1) the $\triangle \mathrm{AMF}$ can become very high (up to about 40 ) indicating the high sensitivity of MAX-DOAS observations; for the other profiles the $\triangle \mathrm{AMF}$ are systematically smaller; the sensitivity decreases with increasing altitude. This difference is caused by the fact that most photons are scattered into the instrument from rather low altitudes. For observations at low elevation angles the absorption paths for trace gases close to the surface are long while those for zenith direction are small. Accordingly, the $\triangle \mathrm{AMF}$ for trace gases located close to the surface are rather large. For trace gases located at higher altitudes, the differences in the absorption paths for the various elevation angles becomes smaller, because part of the photons is scattered below the trace gas layer, and thus the $\triangle \mathrm{AMF}$ decreases. In the presence of additional aerosol scattering, this effect further increases and especially the absorption paths along the line of sight for low elevation angles become shorter. Thus the $\triangle \mathrm{AMF}$ becomes smaller compared to an atmosphere without aerosol scattering. If in cases of strong aerosol scattering the visibility becomes shorter than the vertical extension of the trace gas layer (e.g. in the presence of fog), the trace gas absorption becomes independent on the elevation angle and the $\triangle \mathrm{AMF}$ become zero for all elevation angles (Fig. 2b, c).

We also investigated one very interesting situation: the case that the aerosol (or fog) layer does not reach down to the surface. Figure $2 \mathrm{~d}$ shows $\triangle \mathrm{AMFs}$ for an aerosol layer between 200 and $1200 \mathrm{~m}$ altitude. While the $\mathrm{O}_{4} \Delta \mathrm{AMFs}$ are very small, those for the $\mathrm{BrO}$ profiles are still substantially larger than zero. Especially for the assumed $\mathrm{BrO}$ layer between the surface and $200 \mathrm{~m}(\mathrm{BrO}-1)$, the $\mathrm{BrO} \triangle \mathrm{AMFs}$ are similar to the clear sky case (Fig. 2a). These results are important for the understanding of measurements, where enhanced $\mathrm{BrO} \triangle \mathrm{SCD}$ are accompanied by very small $\mathrm{O}_{4} \triangle \mathrm{SCDs}$ (see Sect. 5.1).

It is interesting to compare the $\triangle \mathrm{AMFs}$ for MAX-DOAS observations with the AMFs for satellite viewing geometry (Fig. 2e, f). For satellite observations, usually a Fraunhofer reference spectrum without tropospheric $\mathrm{BrO}$ absorptions (e.g. an extraterrestrial solar spectrum) is used; thus the result of the spectral analysis represents the total atmospheric slant column density and the appropriate result of radiative transfer modelling is an AMF (instead of $\triangle \mathrm{AMF}$ ). For most cases, the $\triangle \mathrm{AMFs}$ for MAX-DOAS observations are much larger (10-40) than the satellite AMFs $(<1-3)$ indicating the high sensitivity of the MAX-DOAS measurements. It might be inetersting to note that over bright surfaces, the satellite AMF does not strongly depend on the altitude of the Bro layer which makes the satellite measurements a good estimate of the tropospheric column.

Another interesting finding is that the satellite AMFs for $\mathrm{O}_{4}$ are almost independent of the aerosol optical density, and also the AMFs for the BrO profiles stay still clearly above zero (although they decrease substantially with increasing optical density). If the layer of enhanced $\mathrm{BrO}$ concentrations is within the cloud (Fig. 2e) the shielding effect is typically weaker than for cases where the cloud is above the BrO layer (Fig. 2f). Our results indicate that over bright surfaces even in the case of fog or clouds, satellite observations are still sensitive to trace gases close to the ground, indicating that a significant fraction of the photons which have penetrated the aerosol or cloud layer and have traversed the layer below can still reach the satellite instrument.

In a second study, we investigated $\triangle \mathrm{AMF}$ for MAXDOAS observations for various SZA and surface albedos. For these calculations we only considered the elevation angle of $1^{\circ}$, since it exhibits the highest sensitivity for trace gases located close to the surface. We also did not include scattering by aerosols and clouds; thus our results represent only upper limits of the respective $\triangle \mathrm{AMFs}$ (Wagner et al., 2004). However, such upper limits are important to estimate the corresponding lower limits for the tropospheric $\mathrm{BrO}$ $\mathrm{VCD}$ (and the respective boundary layer $\mathrm{BrO}$ concentrations) (see Eq. 2).

The $\triangle \mathrm{AMFs}$ for the different trace gas profiles are shown in Fig. 3a. The $\triangle$ AMFs only slightly depend on the SZA and the surface albedo, making MAX-DOAS observations very sensitive to tropospheric trace gases even at high SZA and low albedo. This advantage becomes especially obvious when the $\triangle \mathrm{AMFs}$ are compared to the AMFs for satellite observations (Fig. 3b). In contrast to the MAX-DOAS ob- 

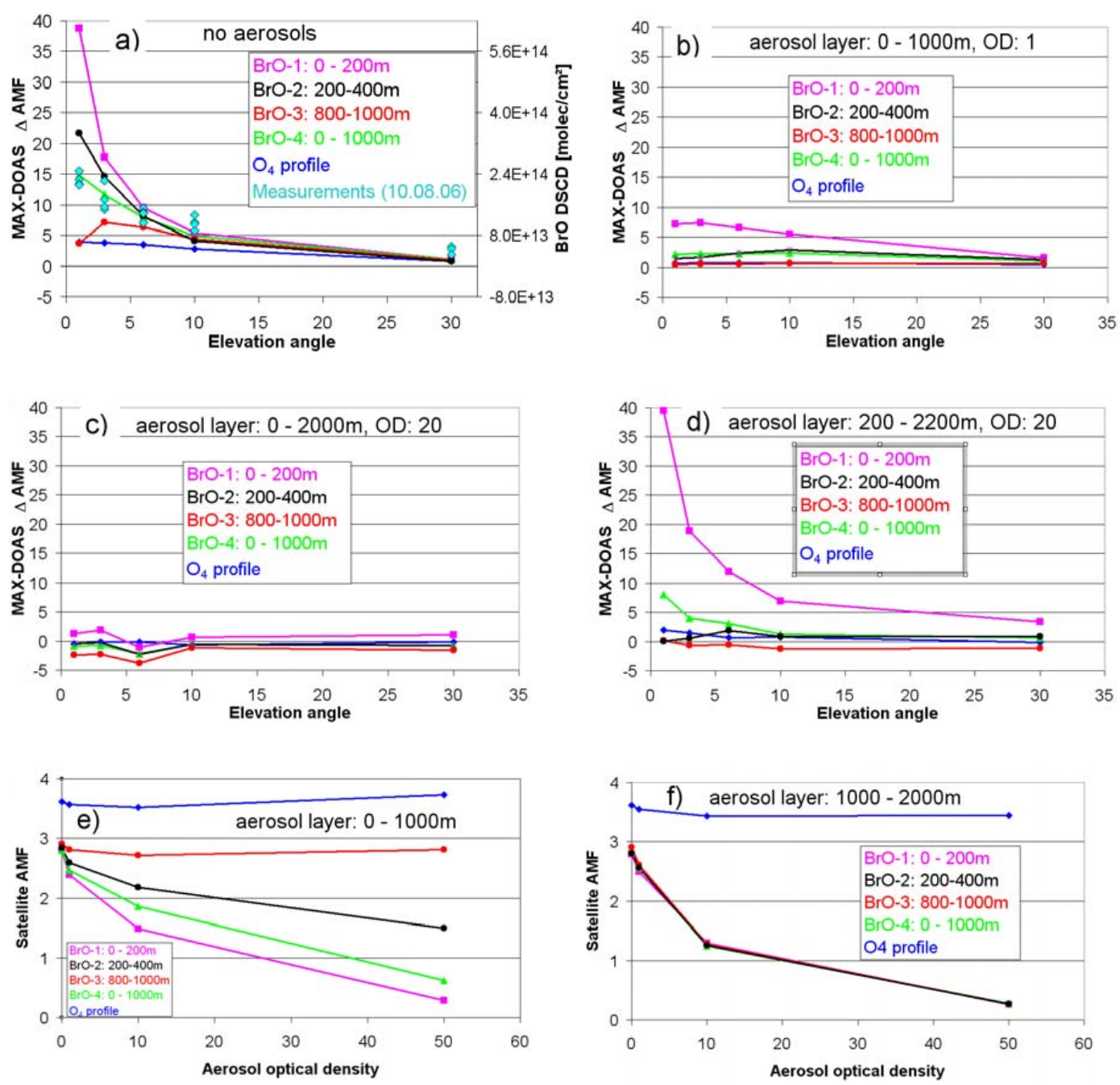

Fig. 2. Modelled sensitivity of MAX-DOAS observations (a-d) and satellite observations (e, f) for different atmospheric conditions over bright surfaces (albedo $=80 \%$ ). The model results for the MAX-DOAS observations are expressed as $\triangle \mathrm{AMFs}$, which are the differences of the AMFs for the low elevation angles and the AMFs for $90^{\circ}$ telescope elevation. The $\triangle \mathrm{AMFs}$ (and also satellite AMFs) are calculated for different height profiles and for different aerosol profiles (altitude range and total optical density indicated in the figures). Our results show that for clear skies the sensitivity of MAX-DOAS observations is about one order of magnitude larger than that of satellite observations. If aerosols are present, the sensitivity for surface-near $\mathrm{BrO}$ is substantially reduced (except for the case that the aerosol layer does not reach the ground, see part d). For satellite observations over high ground albedo, even in the case of high aerosol optical density, the sensitivity for surface near trace gases is still clearly above zero. In part (a) also typical $\mathrm{BrO} \triangle \mathrm{SCD}$ are shown.

servations, the AMFs for satellite viewing geometry strongly decrease with increasing SZA and decreasing albedo.

\section{Results}

In Fig. 4 typical results for selected days of the ship cruise are presented. For the detailed interpretation of the observed $\mathrm{BrO} \triangle \mathrm{SCDs}$ also the simultaneously observed $\mathrm{O}_{4} \Delta \mathrm{SCDs}$ are presented. Furthermore, observations of the horizontal atmospheric visibility and the ceiling height derived from the on board monitoring system of the ship (available via: http://www.awi-bremerhaven.de/MET/Polarstern/ poldatquery.html) are shown. Please note that the visibility is measured from the backscattered light of a xenon flash light in the visible spectral range (Videograph III manufactured by Impulsphysik); and the sensed volume is restricted to a distance $<13 \mathrm{~m}$ from the instrument. In some cases the visibilities measured by this instrument might not be fully representative for those which control the MAX-DOAS observations. The MAX-DOAS observations typically sense a much larger volume, especially also higher altitudes. In addition, especially for fine aerosols, the wavelength dependence of aerosol scattering might lead to slightly shorter visibilities in the UV spectral range. 
a)
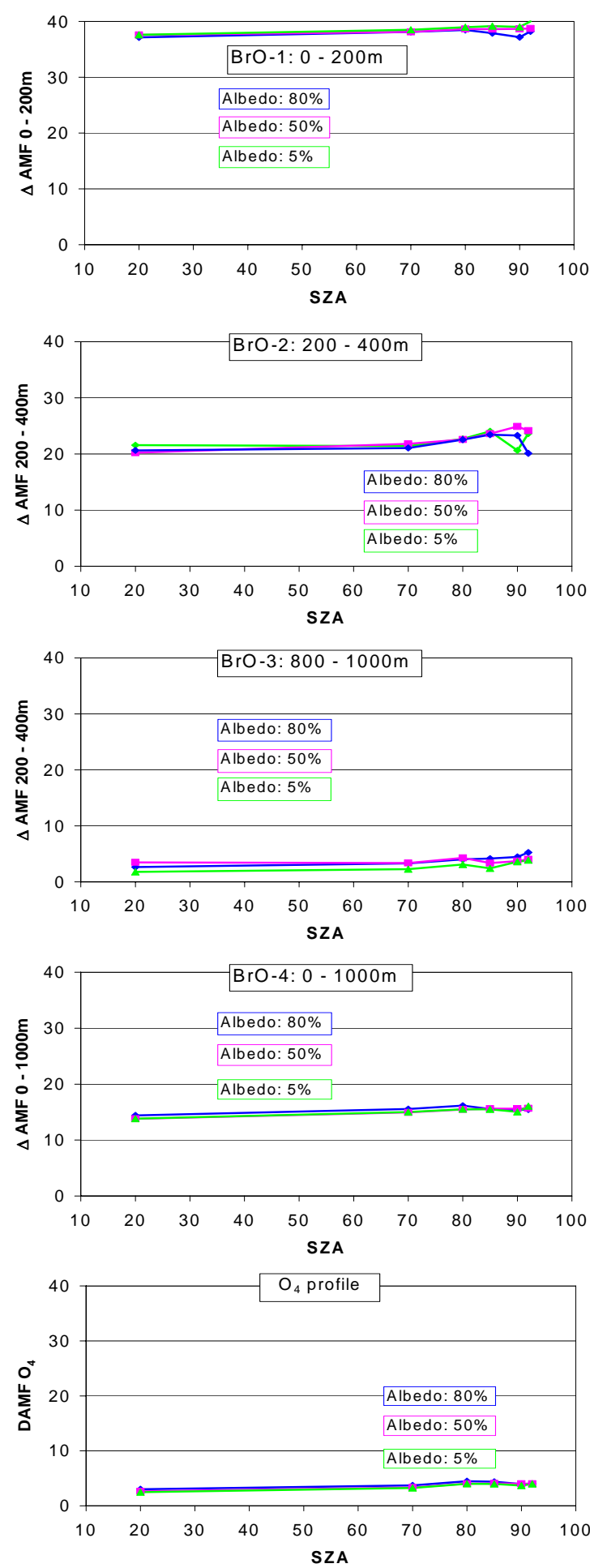

b) Satellite AMF
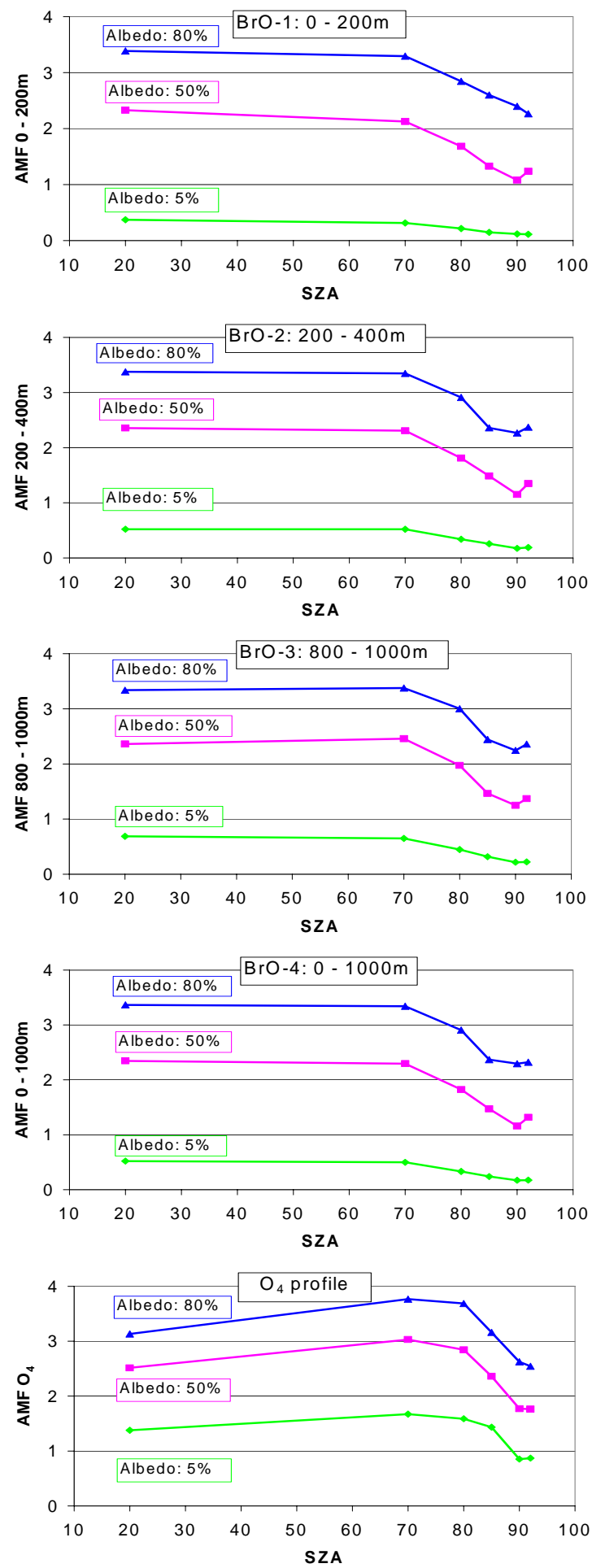

Fig. 3. $\triangle \mathrm{AMFs}$ for MAX-DOAS observations at $1^{\circ}$ elevation angle (left) and AMFs for satellite observations (right) for various values of the surface albedo and different height profiles. While the sensitivity of the satellite observations strongly depends on the surface albedo and the solar zenith angle, the $\triangle \mathrm{AMFs}$ for the MAX-DOAS observations are almost not affected. For the surface near profile the sensitivity of the MAX-DOAS observations is about one order of magnitude larger compared to the satellite observations. 
a)
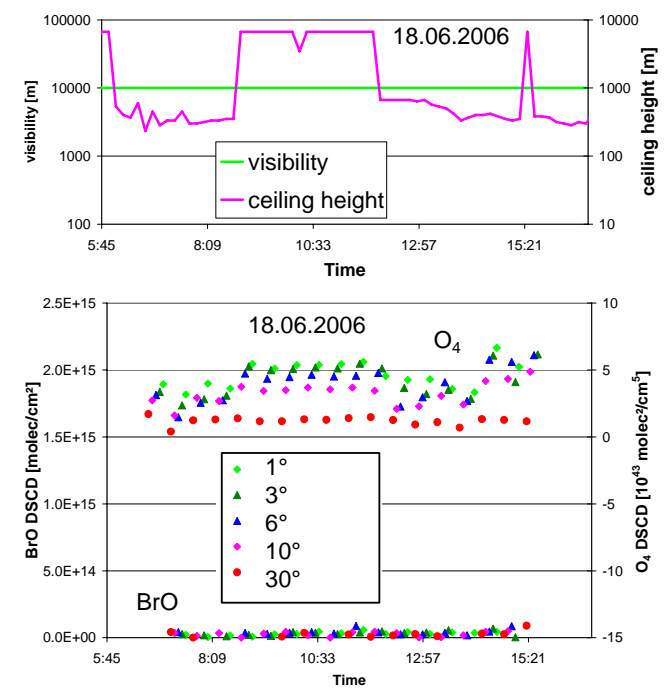

C)
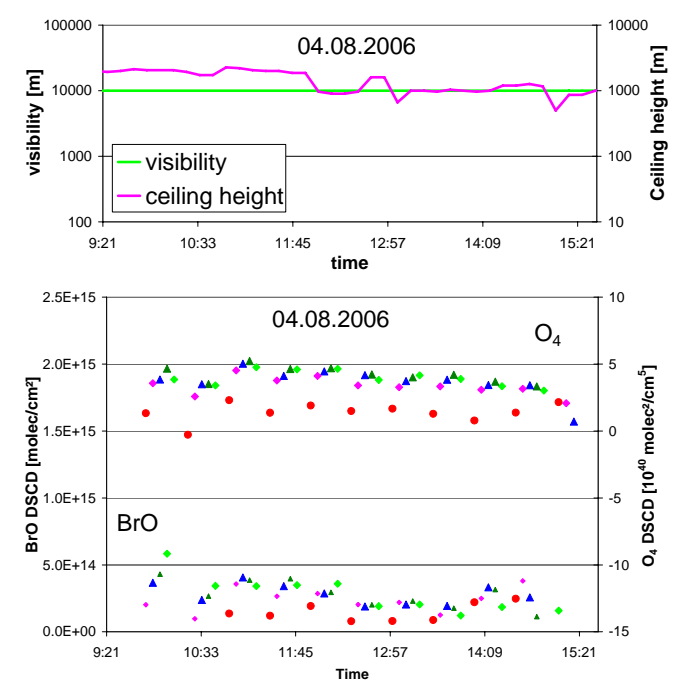

e)
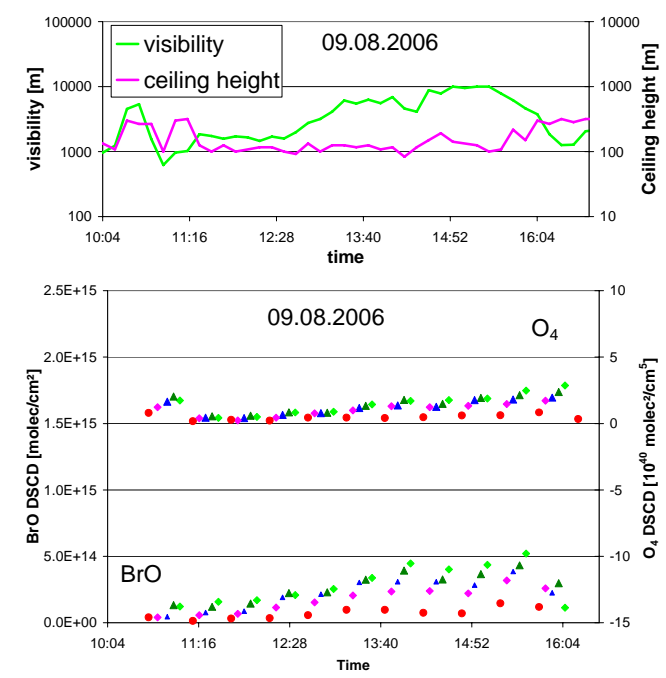

b)
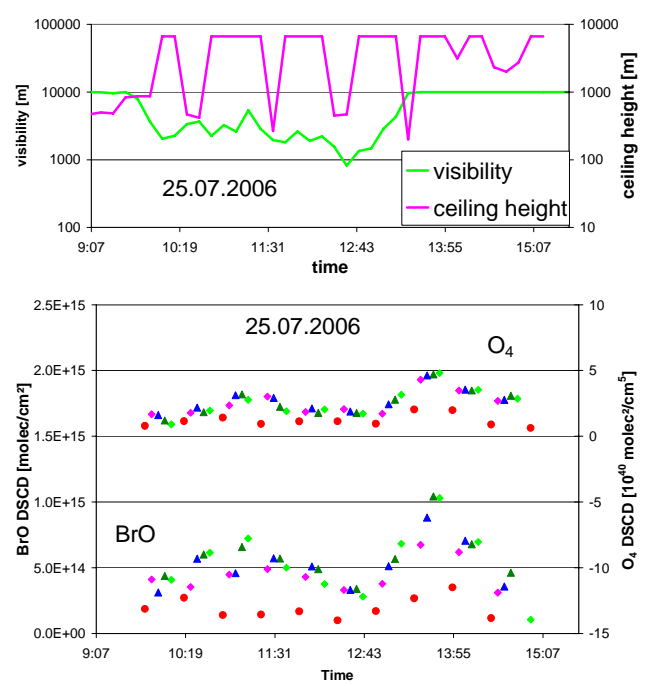

d)
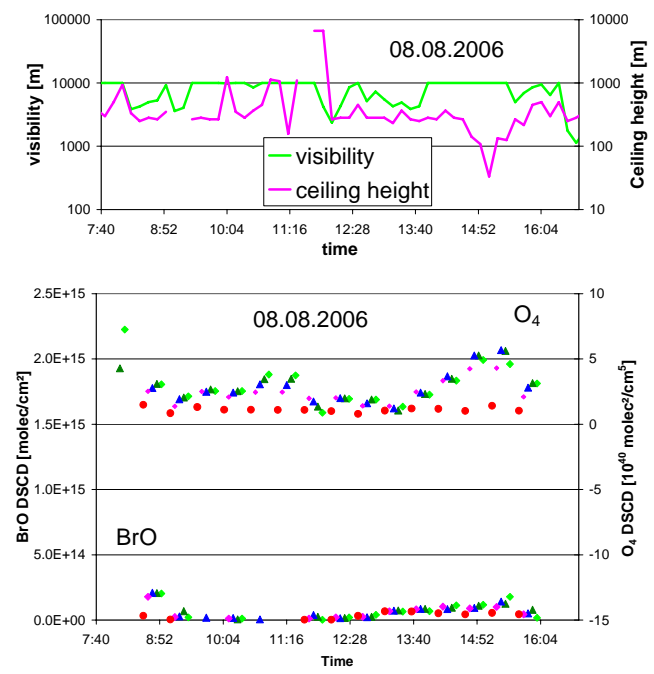

f)
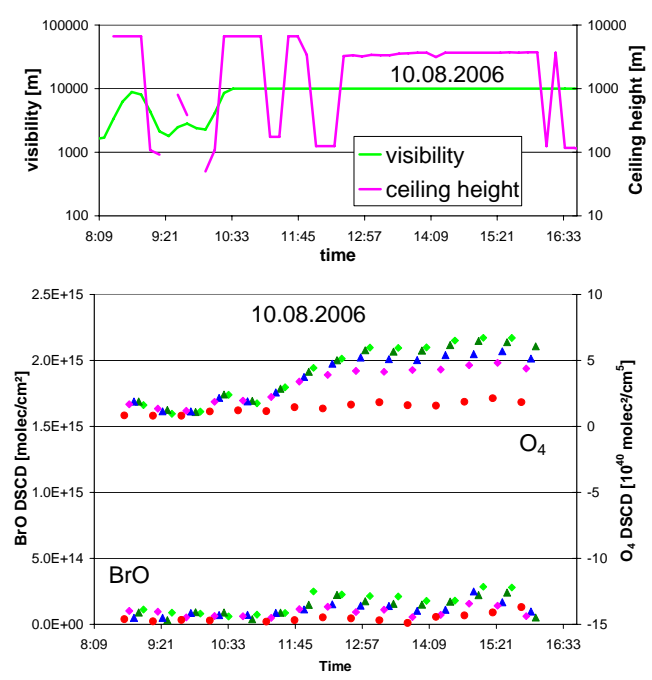

Fig. 4. Measured $\triangle \mathrm{SCDs}$ of $\mathrm{O}_{4}$ and $\mathrm{BrO}$ for selected days during the ship cruise. Also shown are the horizontal visibility and the ceiling height derived from the on board instrumentation. For cloud ceilings above about $1 \mathrm{~km}$, the $\mathrm{O}_{4}$ absorption is mainly limited by the atmospheric visibility. For lower clouds the ceiling height itself becomes also important. High $\mathrm{BrO} \triangle \mathrm{SCD}$ s are observed for almost all observations when the ship was inside the area of first year sea ice (part $\mathbf{b}$ to $\mathbf{f}$, for details see text). 
For cloud ceilings above about $1 \mathrm{~km}$, the $\mathrm{O}_{4}$ absorption is mainly limited by the atmospheric visibility (for an elevation angle of $1^{\circ}$ the geometrical light path between the telescope and the cloud base would be $1 \mathrm{~km} / \sin \left(1^{\circ}\right) \approx 57 \mathrm{~km}$, which is much larger than the visibility at $350 \mathrm{~nm}$ for a clear atmosphere).

In Fig. 4a results for a day before Polarstern reached the sea ice area (18 June 2006) are presented. The $\mathrm{O}_{4} \Delta$ SCDs are high and show a clearly repeating cycle corresponding to the sequence of telescope elevation angles. Such a temporal pattern is obtained if the $\mathrm{O}_{4}$ absorptions at the different elevation angles are systematically different, which is a strong indication for a high atmospheric visibility (in good agreement with the measurements of the on board instrumentation). For the clear sky period of this day the maximum $\mathrm{O}_{4} \Delta \mathrm{SCDs}$ are about $6.5 \cdot 10^{43} \mathrm{molec}^{2} / \mathrm{cm}^{5}$ (e.g. between about 09:00 and 12:00) which is in good agreement with the model results for a clear day (for an $\mathrm{O}_{4} \mathrm{VCD}$ of about $1.3 \cdot 10^{43} \mathrm{molec}^{2} / \mathrm{cm}^{5}$ they correspond to a $\triangle \mathrm{AMF}$ of about 5). Also the onboard measurements of the ceiling height show an almost clear sky for this period. In contrast to the $\mathrm{O}_{4} \triangle \mathrm{SCDs}$, on this day the $\mathrm{BrO} \triangle \mathrm{SCDs}$ show no enhanced values indicating that no enhanced boundary layer $\mathrm{BrO}$ concentration was present. All other results shown in Fig. 4b to $\mathrm{f}$ are derived on days when the ship was inside the area of first year sea ice. On these days typically high $\mathrm{BrO} \triangle \mathrm{SCDs}$ are observed. There are two interesting exceptions: on 8 August 2006 (Fig. 4d) the $\mathrm{BrO} \triangle \mathrm{SCD}$ during the first half of the day are close to zero. Since the $\mathrm{O}_{4} \Delta \mathrm{SCDs}$ of this day are high (also the visibility is relatively high), this indicates that the surface near $\mathrm{BrO}$ concentrations are actually very low. It should be noted that similar results of very low $\mathrm{BrO}$ concentrations were only very rarely found during the whole period the ship was inside the area of first year sea ice (from 24 June 2006-15 August 2006). Low BrO concentrations were only found at the end of 24.07.2006; at the end of 3 August 2006; in the afternoon of 7 August 2006; in the main part of the morning of $8 \mathrm{Au}-$ gust 2006; in the morning and evening of 14 August 2006.

Also in the first half of 10 August 2006 (Fig. 4f) low BrO $\triangle$ SCDs are measured. However, in this case they do very likely not indicate low $\mathrm{BrO}$ concentrations, but rather low atmospheric visibility (as also indicated by the on board measurements and the low $\mathrm{O}_{4} \Delta \mathrm{SCDs}$ ).

\subsection{Information on the $\mathrm{BrO}$ profile from MAX-DOAS ob- servations}

Information on the vertical profile of the $\mathrm{BrO}$ concentrations can be derived in different ways from our observations. One possibility is to study the dependence of the measured $\mathrm{BrO}$ $\triangle \mathrm{SCDs}$ on the elevation angle (see Fig. 2). If e.g. the maximum concentration was located close to the surface, the dependence of the $\mathrm{BrO} \triangle \mathrm{SCDs}$ on elevation angle should be rather strong; in particular the $\mathrm{BrO} \triangle \mathrm{SCDs}$ at $1^{\circ}$ elevation should be much larger than those at $3^{\circ}$. Surprisingly, for no observation during the whole campaign, we found that strong increase of the $\mathrm{BrO} \triangle \mathrm{SCD}$ for decreasing elevation angle. It is important to note that for individual observations, several effects (or also their combination) might cause a strongly reduced dependence of the $\mathrm{BrO} \triangle \mathrm{SCD}$ on elevation angle. If e.g. aerosols are present, they can reduce the photon paths along the lines of sight, and thus the difference of the $\mathrm{BrO}$ $\triangle$ SCDs at low elevation angles. In addition, also ice layers at the telescope and/or the ship movement might cause an increase of the field of view of the telescope, which would also cause a reduced difference of the $\mathrm{BrO} \triangle \mathrm{SCD}$ at low elevation angles. Thus we would understand if for individual measurement sequences, the observed dependence of the $\mathrm{BrO} \triangle \mathrm{SCDs}$ on elevation angle could be reduced (while high $\mathrm{BrO}$ concentrations were still present close to the ground). Nevertheless, during the whole campaign we found no single observation sequence (not even for days with high visibility, high ceiling height, and also high observed $\mathrm{O}_{4}$ absorption), for which the increase of the BrO $\triangle \mathrm{SCD}$ for low elevation angles was in agreement with the model results for a $\mathrm{BrO}$ layer close to the ground (a typical example for the measured sequence of $\mathrm{BrO} \triangle \mathrm{SCDs}$ is shown in Fig. 2a). From these findings we conclude that the major fraction of the $\mathrm{BrO}$ concentrations is typically not located close to the surface but at higher altitudes.

It is interesting to note here that previous MAX-DOAS observations of polar boundary layer $\mathrm{BrO}$ (e.g. Hönninger and Platt, 2002; Hönninger et al., 2004) were not sensitive enough to yield similar height information, because of the lack of observations at low elevation angles.

Another way to estimate the vertical distribution of the $\mathrm{BrO}$ concentration is to investigate the influence of clouds on the measurements. On some days (e.g. 25 July 2006 and 9 August 2006, see Fig. 4b, e) high $\mathrm{BrO} \Delta \mathrm{SCDs}$, but rather low $\mathrm{O}_{4} \Delta$ SCDs are observed. Especially on 9 August 2006 the cloud ceiling (between about 100 and $200 \mathrm{~m}$ ) and the visibility were very low. The enhanced $\mathrm{BrO} \triangle \mathrm{SCD}$ indicate that high $\mathrm{BrO}$ concentrations have been mainly present below the cloud.

Combining the two findings we conclude that during the period when the ship was within the sea ice, typically the $\mathrm{BrO}$ concentrations increased from the surface with increasing altitude. The maximum concentrations are probably located around the upper edge of the boundary layer, possibly reaching partly into the free troposphere. Depending on the vertical extension of the boundary layer, the thickness of the layer with maximum $\mathrm{BrO}$ concentrations might be several hundred metres. Occasional occurrence of BrO layers elevated from the ground were also reported by Hönninger et al. (2004b). 


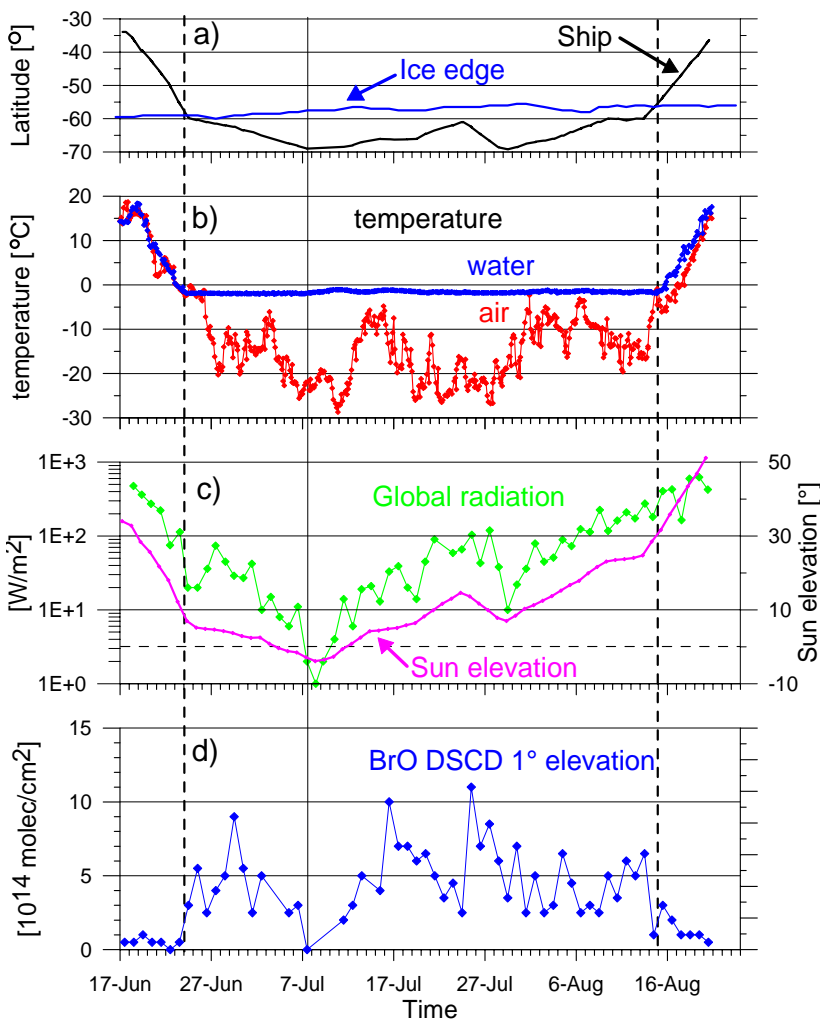

Fig. 5. Daily maximum $\mathrm{BrO} \triangle \mathrm{SCD}$ for $1^{\circ}$ elevation angle (d). Also shown are the latitude of the ship and the ice edge (a), the temperatures of air and water (b) as well as daily maximum values of the global radiation and the sun elevation (c). High BrO $\triangle$ SCDs are only found for measurements within the area of first year sea ice (indicated also by the water temperature $<0^{\circ} \mathrm{C}$ ). For low sun elevation $\left(<-2.8^{\circ}\right)$ also no enhanced $\mathrm{BrO} \triangle \mathrm{SCDs}$ were found.

5.2 Overview on the whole cruise and relation of the observed $\mathrm{BrO} \triangle \mathrm{SCDs}$ to the duration of sea ice contact

In Figs. 5 and 6 the daily maximum $\mathrm{BrO} \triangle \mathrm{SCDs}$ are presented from 17 June 2006 until 21 August 2006. In addition, also the latitude of the ship and that of the ice edge, the daily maximum global radiation (from the on board instrumentation), the daily maximum sun elevation angle as well as the temperatures of the air and the water are shown. The period when the ship was inside the sea ice can be clearly determined from the latitude plot and the time when the water temperatures were below zero. Outside the first year sea ice belt, only small $\mathrm{BrO} \triangle \mathrm{SCD}$ were observed. Enhanced $\mathrm{BrO}$ $\triangle \mathrm{SCDs}$ are almost entirely found during the period when the ship was within the area of first year sea ice. One interesting exception appeared on 7 July 2006. On this day the sun elevation was very low $\left(<-2.8^{\circ}\right)$ possibly indicating that the photolysis of $\mathrm{Br}_{2}$ might have been too slow to provide sufficient amounts of $\mathrm{Br}$ radicals that can react with $\mathrm{O}_{3}$ to BrO. On the previous day (6 July 2006) the sun elevation reached a maximum value of $-1.5^{\circ}$ and still enhanced $\mathrm{BrO}$

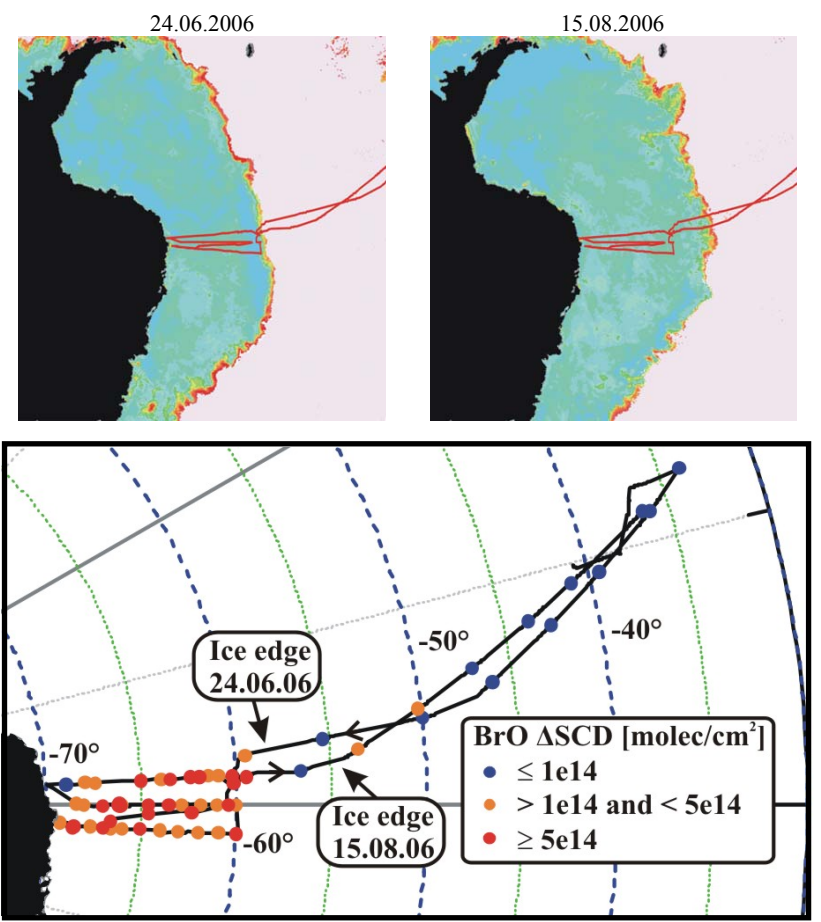

Fig. 6. Top: area of first year sea ice for 24 June 2006 and 15 August 2006 (sea ice data are from the web page of the sea ice group of the National Centers for Environmental Prediction (NCEP) and the Marine Modelling and Analysis Branch (MMAB) (http://polar. ncep.noaa.gov/seaice/). Between these dates the ship was inside the area of first year sea ice. Bottom: daily maximum $\mathrm{BrO} \Delta \mathrm{SCD}$ for $1^{\circ}$ elevation angle. High values are almost exclusively found for measurements within the area of first year sea ice.

$\triangle \mathrm{SCDs}$ were observed. It should, however, be noted that for measurements with sun elevation $<0^{\circ}$ the measurement error can become very large and the respective $\mathrm{BrO} \triangle \mathrm{SCDs}$ might only be seen as an indicator for the true $\mathrm{BrO} \Delta \mathrm{SCD}$. For such conditions, from the spectroscopic results alone it is not possible to derive unambiguous conclusions on the significance of the results. Days with such large errors include the 6 July 2006, 7 July 2006, 11 July 2006, and 13 July 2006 when the optical density of the residual was up to $3 \%$. For several other days during low sun elevation, the residual was even larger and no meaningful retrievals were possible at all.

Our measurements indicate that enhanced boundary layer $\mathrm{BrO}$ concentrations almost continuously exist over the sea ice for the whole period the ship was present there. After the ship left the area of first year sea ice, again only low $\mathrm{BrO}$ $\triangle$ SCDs were found indicating a short lifetime of the activated bromine compounds. Another important finding is that events of enhanced $\mathrm{BrO}$ concentrations are observed by the MAX-DOAS observations about one month earlier than from satellite observations (Wagner et al., 2001).

To further investigate the variation of the daily maximum $\mathrm{BrO} \triangle \mathrm{SCDs}$ we performed trajectory analyses using the the 
HYSPLIT model (HYbrid Single-Particle Lagrangian Integrated Trajectory Model, access via NOAA ARL READY Website (http://www.arl.noaa.gov/ready/hysplit4.html, see Draxler and Hess, 1998). For every day (at noon) we calculated back trajectories and estimated the duration for which the air masses have been in contact to the sea ice surface during the preceding days. We correlated the daily maximum BrO $\triangle$ SCDs with the estimated duration of sea ice contact. Our results (Fig. 7) show a weak correlation, similar to those found by Friess et al. (2004), Simpson et al. (2007b). Part of the scatter might be caused by simplifications of the trajectory analysis (only one trajectory per day, analysis done "by eye") and also by variations of the meteorological conditions. Especially changes of the visibility and boundary layer height would significantly affect the sensitivity of the MAX-DOAS observations (see Sect. 4).

\subsection{Estimation of the $\mathrm{BrO}$ mixing ratios}

Using the modelled $\triangle \mathrm{AMF}$ we can convert the measured $\triangle \mathrm{SCDs}$ into $\mathrm{BrO}$ concentrations and $\mathrm{BrO}$ mixing ratios. We apply this conversion for the telescope elevation of $1^{\circ}$ and we consider again the $\mathrm{BrO}$ profiles described in Sect. 4.2. We also assume clear sky conditions, thus our conversion represents a lower limit for the true $\mathrm{BrO}$ concentrations.

In Table 1 the results of the derived $\mathrm{BrO}$ mixing ratios are presented, which strongly depend on the assumed altitude profile. They increase with increasing altitude of the $\mathrm{BrO}$ layer (effect of decreasing $\triangle \mathrm{AMF}$ ) and decrease with increasing vertical extension of the layer. The values shown in Table 1 are calculated for typical measured BrO $\triangle$ SCDs $\left(0.5 \cdot 10^{15} \mathrm{molec} / \mathrm{cm}^{2}\right)$ and maximum values $\left(10^{15} \mathrm{molec} / \mathrm{cm}^{2}\right)$.

The derived mixing ratios cover a wide range. Low values are calculated for cases with a vertically extended boundary layer. Very high values are calculated assuming a shallow layer at high altitudes.

Assuming profiles with increasing concentrations with altitude leads to values in the order of several ten ppt. These values are rather high, but in overall agreement with other measurements (e.g. Tuckermann et al., 1997; Wagner and Platt, 1998; Hönninger and Platt, 2002; Hönninger et al., 2004a, b). If, as concluded from our observations, the maximum $\mathrm{BrO}$ concentration is not located directly above the ground, this could explain the rather high mixing ratios compared to ground based observations or satellite observations. It might be also interesting to note that in contrast to these measurements, almost all other observations were made in the northern hemisphere.

\section{Discussion and conclusions}

We performed MAX-DOAS observations of tropospheric $\mathrm{BrO}$ on board the German research vessel Polarstern during

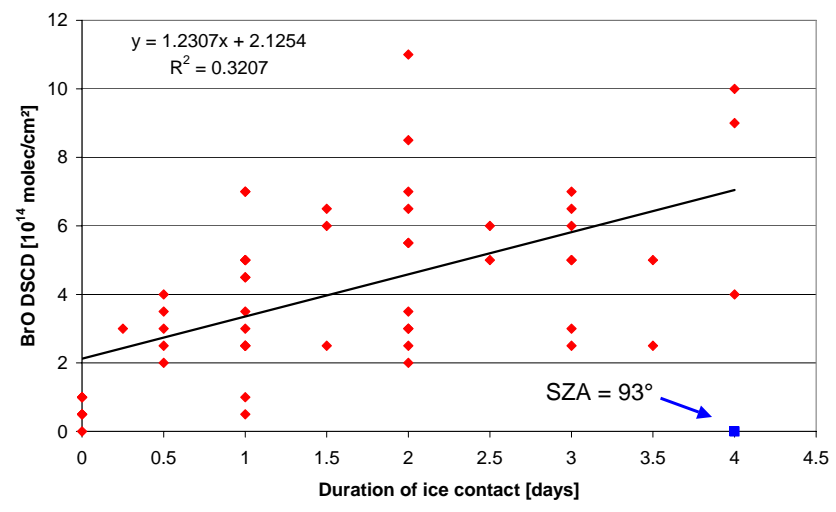

Fig. 7. Correlation of the daily maximum $\mathrm{BrO} \Delta \mathrm{SCD}$ with the duration of the air masses with the sea ice surface prior to the measurements. The duration of sea ice contact was estimated from back trajectories calculations using the HYSPLIT model (http: //www.arl.noaa.gov/ready/hysplit4.html). For the measurements on 7 July 2006 low BrO $\triangle$ SCDs were found although the air masses have had extended contact to sea ice.

the Antarctic winter 2006. The Polarstern entered the area of first year sea ice around Antarctica on 24 June 2006 and stayed within this area until 15 August 2006. For the period inside the area of first year sea ice, enhanced $\mathrm{BrO}$ concentrations were almost continuously observed. Before and after the period inside the first year sea ice, typically low $\mathrm{BrO}$ concentrations are observed. The small $\mathrm{BrO}$ concentrations over the open ocean indicate that either the observed air masses did not originate from the areas of first year sae ice or that the atmospheric lifetime of activated bromine compounds is to short to maintain high $\mathrm{BrO}$ concentrations after the contact to areas of first year sea ice. Based on back trajectory calculations we found a positive correlation between the magnitude of the observed $\mathrm{BrO} \triangle \mathrm{SCDs}$ and the duration for which the air masses have been in contact with the sea ice surface prior to the measurement.

From the MAX-DOAS measurements and meteorological observations, it was possible to retrieve information on the vertical distribution of the $\mathrm{BrO}$ concentration. For days with very low cloud ceiling (e.g. between 100 and $200 \mathrm{~m}$ ), still enhanced $\mathrm{BrO} \triangle \mathrm{SCDs}$ were observed (in contrast to those of $\mathrm{O}_{4}$ ) indicating that enhanced $\mathrm{BrO}$ concentrations are present mainly below the clouds. Additional information on the shape of the $\mathrm{BrO}$ concentration profile was derived from the dependence of the $\mathrm{BrO} \triangle \mathrm{SCD}$ on the elevation angle. While we can not completely rule out that the maximum $\mathrm{BrO}$ concentrations are located close to the ground, this dependence indicates that the highest $\mathrm{BrO}$ concentrations might be typically located at higher altitudes. From both findings we conclude that the $\mathrm{BrO}$ concentration profile should have a maximum close to the upper edge of the boundary layer with decreasing concentrations towards the surface. Depending on the vertical extension of the boundary layer, the thickness 
Table 1. Estimated $\mathrm{BrO}$ mixing ratios for different assumed profiles and $\mathrm{BrO} \Delta \mathrm{SCDs}$.

\begin{tabular}{|c|c|c|c|}
\hline BrO concentration profile & $\mathrm{AMF}$ & $\begin{array}{l}\text { Mixing ratio (in ppt) } \\
\text { for maximum BrO } \Delta \mathrm{SCD} \\
\left(10^{15} \text { molec } / \mathrm{cm}^{2} \text {, see Fig. 5) }\right.\end{array}$ & $\begin{array}{l}\text { Mixing ratio (in ppt) } \\
\text { for typical } \mathrm{BrO} \triangle \mathrm{SCD} \\
\left(0.5 \cdot 10^{15} \mathrm{molec} / \mathrm{cm}^{2} \text {, see Fig. } 5\right)\end{array}$ \\
\hline constant from 0-200 m & 39 & 50 & 25 \\
\hline constant from $200-400 \mathrm{~m}$ & 22 & 88.5 & 44 \\
\hline constant from $400-600 \mathrm{~m}$ & 13 & 150 & 75 \\
\hline constant from $600-800 \mathrm{~m}$ & 8 & 243 & 121 \\
\hline constant from $800-1000 \mathrm{~m}$ & 4 & 487 & 243 \\
\hline constant from $0-1000 \mathrm{~m}$ & 15 & 26 & 13 \\
\hline $\begin{array}{l}\text { linear increase from } 0-200 \mathrm{~m} \text {, } \\
\text { constant from } 200-400 \mathrm{~m}\end{array}$ & 28 & $46^{*}$ & $23 *$ \\
\hline $\begin{array}{l}\text { linear increase from } 0-400 \mathrm{~m} \text {, } \\
\text { constant from } 400-600 \mathrm{~m}\end{array}$ & 15 & $65^{*}$ & $32 *$ \\
\hline
\end{tabular}

* mixing ratios for the upper part of the profiles.

of the layer with maximum $\mathrm{BrO}$ concentrations might be several hundred metres.

Such profiles are in good agreement with the studies of von Glasow and Sander (2001) and von Glasow et al. (2002), who found decreasing sea salt $\mathrm{pH}$ and increasing $\mathrm{BrO}$ concentrations with increasing altitude. It is interesting to note that according to the studies of Lehrer et al. (2004) and Piot et al. (2007), recycling of active bromine on aerosols can also play an important in maintaining high $\mathrm{BrO}$ concentrations apart from recycling at the surface.

An additional reason for the maximum BrO concentration around the upper edge of the boundary layer might be related to vertical transport processes: while on the one hand the temperature profiles of the radio sonde observations made at Polarstern (from upper air soundings, http: //www.awi-bremerhaven.de/MET/Polarstern/raso.html) typically indicate very stable inversion layers, it is on the other hand very probable that often rapid changes of these inversion layers might occur, e.g. when the variation between warm ocean and cold the sea ice surfaces lead to strong temperature gradients. The resulting convective vertical air motion and related mixing might cause effective transport of ozone-rich air masses from the free troposphere into the boundary layer and transport of air masses with activated bromine compounds from the boundary layer into the free troposphere. Assuming such transport processes should lead to a maximum $\mathrm{BrO}$ concentration around the upper edge of the boundary layer.

The existence of strong vertical gradients of $\mathrm{BrO}$ and $\mathrm{O}_{3}$ might also have an additional important implication: the observation of an almost continuously enhanced BrO $\triangle$ SCDs during the whole ship cruise within the sea ice would be difficult to explain under the assumption of a continuously stable inversion layer. In this case one would expect that after a few days all $\mathrm{O}_{3}$ should be destroyed and accordingly also no $\mathrm{BrO}$ could be formed any more. The observation of continuously enhanced $\mathrm{BrO} \triangle \mathrm{SCD}$ indicates that vertical mixing processes and vertical gradients of $\mathrm{O}_{3}$ and $\mathrm{BrO}$ might play an important role. Unfortunately, during this ship cruise no ozone data from in-situ measurements or ozone sondes are available to compare with our $\mathrm{BrO}$ observations.

The measured $\mathrm{BrO} \triangle \mathrm{SCDs}$ can be converted into mixing ratios assuming a vertical profile for the BrO concentration. For BrO concentration profile with linearly increasing concentrations from the surface to $200 \mathrm{~m}(400 \mathrm{~m})$ and constant concentrations between $200 \mathrm{~m}$ and $400 \mathrm{~m}$ (400 and $600 \mathrm{~m}$ ), typical $\mathrm{BrO}$ mixing ratios in the order of several ten ppt are derived from our measurements (see Table 1). These values are rather high compared with other measurements (e.g. Tuckermann et al., 1997; Wagner and Platt, 1998; Hönninger and Platt, 2002; Hönninger et al., 2004a, b). The differences might be mainly related to our findings on the vertical profile shape. It is especially interesting to note here that previous MAX-DOAS observations of polar boundary layer BrO (e.g. Hönninger and Platt, 2002; Hönninger et al., $2004 a, b)$ were not sensitive enough to yield similar height information, because of the lack of observations at low elevation angles.

For large parts of our measurements the solar elevation was very low or even below the horizon. For such conditions, the atmospheric photolysis rates decrease, Br levels drop and most reactive $\mathrm{Br}$-compounds will exist as $\mathrm{Br}_{2}$ molecules. As a consequence, ozone destruction and the removal of reactive compounds due to reaction of $\mathrm{BrO}$ with $\mathrm{HO}_{2}, \mathrm{HCHO}$ and olefins will be substantially reduced. On one day (7 July 2006) with very low sun elevation (maximum elevation angle $<-2.8^{\circ}$ ) we indeed found $\mathrm{BrO} \triangle \mathrm{SCD}$ close to zero, although the air masses have had extended contact (about 4 days) with the sea ice surface. These measurements might be an indication for the decreasing concentration of $\mathrm{Br}$ atoms for low light conditions. However, our observations should be seen only as a hint since the measurement uncertainties are very high for this day. 
Our MAX-DOAS observations found enhanced $\mathrm{BrO}$ concentrations about one month earlier than analysed from satellite observations (Wagner et al., 2001). From detailed radiative transfer simulations we find that MAX-DOAS observations are typically (except situations with strongly reduced visibility, e.g. caused by fog) about one order of magnitude more sensitive compared to satellite observations. In contrast to satellite observations their sensitivity does hardly decrease for large solar zenith angles and low albedo. Thus they are very well suited for observations in polar regions close to the solar terminator.

Acknowledgements. We like to thank the Alfred Wegner Institute in Bremerhaven for providing the opportunity to perform the MAX-DOAS observation on board of the research vessel Polarstern. Very special thanks are expressed to the crew, and in particular P. Gerschow, S. El Dine El Naggar, M. Rutgers van der Loeff and C. Schlosser for their great support. The onboard data are from the web-interface (http: //www.awi-bremerhaven.de/MET/Polarstern/poldatquery.html) managed by G. König-Langlo, and the sea ice data are from the web page of the sea ice group of the National Centers for Environmental Prediction (NCEP) and the Marine Modelling and Analysis Branch (MMAB) (http://polar.ncep.noaa.gov/seaice/). The authors gratefully acknowledge the NOAA Air Resources Laboratory (ARL) for the provision of the HYSPLIT transport and dispersion model and/or READY website (http://www.arl.noaa.gov/ready.html) used in this publication. We want to thank L. Kaleschke and R. Sander for very stimulating discussions and W. Simpson and another anonymous referee for their inspiring suggestions.

Edited by: A. Richter

\section{References}

Barrie, L. A., Bottenheim, J. W., Schnell, R. C., Crutzen, P. J., and Rasmussen, R. A.: Ozone destruction and photochemical reactions at polar sunrise in the lower Arctic atmosphere, Nature, 334, 138-141, 1988.

Bogumil, K., Orphal, J., Homann, T., Voigt, S., Spietz, P., Fleischmann, O. C., Vogel, A., Hartmann, M., Bovensmann, H., Frerik, J., and Burrows, J. P.: Measurements of Molecular Absorption Spectra with the SCIAMACHY Pre-Flight Model: Instrument Characterization and Reference Data for Atmospheric Remote-Sensing in the 230-2380 nm Region, J. Photochem. Photobiol. A., 157, 167-184, 2003.

Bottenheim, J. W., Gallant, A. C., and Brice, K. A.: Measurements of $\mathrm{NO}_{\mathrm{y}}$ species and $\mathrm{O}_{3}$ at $82^{\circ} \mathrm{N}$ latitude, Geophys. Res. Lett., 13, 113-116, 1986.

Burrows, J. P., Weber, M., Buchwitz, M., Rozanov, V., LadstätterWeißenmayer, A., Richter, A., DeBeek, R., Hoogen, R., Bramstedt, K., Eichmann, K.-U., Eisinger, M., and Perner, D.: The Global Ozone Monitoring Experiment (GOME): Mission Concept and First Scientific Results, J. Atmos. Sci., 56, 151-175, 1999.

Deutschmann, T. and Wagner, T.: TRACY-II Users manual, University of Heidelberg, 2006.
Domine, F., Sparapani, R., Ianniello, A., and Beine, H. J.: The origin of sea salt in snow on Arctic sea ice and in coastal regions, Atmos. Chem. Phys., 4, 2259-2271, 2004, http://www.atmos-chem-phys.net/4/2259/2004/.

Draxler, R. R. and Hess, G. D.: An Overview of the Hysplit_4 Modeling System for Trajectories, Dispersion, and Deposition, Aust. Met. Mag., 47, 295-308,1998.

ESA Publication Division (SP-1182): GOME, Global Ozone Monitoring Experiment, users manual, edited by: Bednarz, F., European Space Research and Technology Centre (ESTEC), Frascati, Italy, 1995.

Frieß, U., Hollwedel, J., Koenig-Langlo, G., Wagner, T., Platt, U.: Dynamics and chemistry of tropospheric bromine explosion events in the Antarctic, J. Geophys. Res., 109, D06305, doi:10.1029/2003JD004133, 2004.

Frieß, U., Monks, P. S., Remedios, J. J., Rozanov, A., Sinreich, R., Wagner, T., and Platt, U.: MAX-DOAS O4 measurements: A new technique to derive information on atmospheric aerosols. (II) Modelling studies, J. Geophys. Res., 111, D14203, doi:10.1029/2005JD006618, 2006.

Grainger, J. F. and Ring, J.: Anomalous Fraunhofer line profiles, Nature, 193, 762, 1962.

Greenblatt, G. D., Orlando, J. J., Burkholder, J. B., and Ravishankara, A. R.: Absorption measurements of oxygen between 330 and 1140 nm, J. Geophys. Res., 95, 18 577-18 582, 1990.

Hausmann, M. and Platt, U.: Spectroscopic measurement of bromine oxide and ozone in the high Arctic during Polar Sunrise Experiment 1992, J. Geophys. Res., 99, 25 399-25 414, 1994.

Heckel, A., Richter, A., Tarsu, T., Wittrock, F., Hak, C., Pundt, I., Junkermann, W., and Burrows, J. P.: MAX-DOAS measurements of formaldehyde in the Po-Valley, Atmos. Chem. Phys., 5, 909918, 2005, http://www.atmos-chem-phys.net/5/909/2005/.

Hönninger, G. and Platt, U.: Observations of $\mathrm{BrO}$ and its vertical distribution during surface ozone depletion at Alert, Atmos. Environ., 36, 2481-2490, 2002.

Hönninger, G., von Friedeburg, C., and Platt, U.: Multi Axis Differential Optical Absorption Spectroscopy (MAX-DOAS), Atmos. Chem. Phys., 4, 231-254, 2004a.

Hönninger, G., Leser, H., Sebastian, O., and Platt, U.: Groundbased Measurements of Halogen Oxides at the Hudson Bay by Active Long Path DOAS and Passive MAX-DOAS, Geophys. Res. Lett., 31, L04111, doi:10.1029/2003GL018982, 2004b.

Hollwedel, J., Wenig, M., Beirle, S., Kraus, S., Kühl, S., WilmsGrabe, W., Platt, U., and Wagner, T.: Year-to-year variations of spring time polar tropospheric $\mathrm{BrO}$ as seen by GOME, Adv. Space Res., 34, 804-808, 2004.

Jacobi, H.-W., Kaleschke, L., Richter, A., Rozanov, A., and Burrows, J. P.: Observation of a fast ozone loss in the marginal ice zone of the Arctic Ocean, J. Geophys. Res., 111, D15309, doi:10.1029/2005JD006715, 2006.

Kaleschke, L., Richter, A., Burrows, J. P., Afe, O., Heygster, G., Notholt, J., Rankin, A. M., Roscoe, H. K., Hollwedel, J., Wagner, T., and Jacobi, H.-W.: Frost flowers on sea ice as a source of sea salt and their influence on tropospheric halogen chemistry, Geophys. Res. Lett., 31, L16114, doi:10.1029/2004GL020655, 2004.

Kreher, K., Johnston, P. V., Wood, S. W., and Platt, U.: Groundbased measurements of tropospheric and stratospheric BrO at Ar- 
rival Heights ( $\left.78^{\circ} \mathrm{S}\right)$, Antarctica, Geophys. Res. Lett., 24, 30213024, 1997.

Kurucz, R. L., Furenlid, I., Brault, J., and Testerman, L.: Solar flux atlas from $296 \mathrm{~nm}$ to $1300 \mathrm{~nm}$, National Solar Observatory Atlas No. 1, 1984.

Leser, H., Hönninger, G., and Platt, U.: MAX-DOAS measurements of $\mathrm{BrO}$ and $\mathrm{NO} 2$ in the marine boundary layer, Geophys. Res. Lett., 30(10), doi:10.1029/2002GL015811, 2003.

Marquard, L. C., Wagner, T., and Platt, U.: Improved Air Mass Factor Concepts for Scattered Radiation Differential Optical Absorption Spectroscopy of Atmospheric Species, J. Geophys. Res., 105, 1315-1327, 2000.

Noxon, J. F., Whipple, E. C., and Hyde, R. S.: Stratospheric $\mathrm{NO}_{2} .1$. Observational method and behaviour at midlatitudes, J. Geophys. Res., 84, 5047-5076, 1979.

Oltmans, S. J. and Komhyr, W. D.: Surface ozone distributions and variations from 1973-1984 measurements at the NOAA geophysical monitoring for climatic change baseline observatories, J. Geophys. Res., 91, 5229-5236, 1986.

Piot, M. and von Glasow, R.: The potential importance of frost flowers, recycling on snow, and open leads for Ozone Depletion Events, Atmos. Chem. Phys. Discuss., 7, 4521-4595, 2007, http://www.atmos-chem-phys-discuss.net/7/4521/2007/.

Platt, U. and Lehrer, E.: ARCTOC final report to EU, Brussels, 1996.

Richter, A., Wittrock, F., Eisinger, M., and Burrows, J. P.: GOME observations of tropospheric $\mathrm{BrO}$ in northern hemispheric spring and summer 1997, Geophys. Res. Lett., 25, 2683-2686, 1998.

Richter, A., Wittrock, F., Ladstätter-Weißenmayer, A., and Burrows, J. P.: GOME measurements of stratospheric and tropospheric BrO, Adv. Space Res., 29(11), 1667-1672, 2002.

Sander, R., Burrows, J., and Kaleschke, L.: Carbonate precipitation in brine the trigger for tropospheric ozone depletion events, Atmos. Chem. Phys., 6, 4653-4658, 2006,

http://www.atmos-chem-phys.net/6/4653/2006/.

Simpson, W. R., Alvarez-Aviles, L., Douglas, T. A., Sturm, M., and Domine, F.: Halogens in the coastal snow pack near Barrow, Alaska: Evidence for active bromine airsnow chemistry during springtime, Geophys. Res. Lett., 32, doi:10.1029/2004GL021748, 2005.

Simpson, W. R., von Glasow, R., Riedel, K., et al.: Halogens and their role in polar boundary-layer ozone depletion, Atmos. Chem. Phys. Discuss., 7, 4285-4403, 2007a.

Simpson, W. R., Carlson, D., Hoenninger, G., Douglas, T. A., Sturm, M., Perovich, D. K., and Platt, U.: First-year sea-ice contact predicts bromine monoxide $(\mathrm{BrO})$ levels better than potential frost flower contact, Atmos. Chem. Phys., 7, 621-627, $2007 \mathrm{~b}$.

Sinreich, R., Frieß, U., Wagner, T., and Platt, U.: Multi axis differential optical absorption spectroscopy (MAX-DOAS) of gas and aerosol distributions, Faraday Discuss., 130, doi:10.1039/b419274, 2005.

Solberg, S., Schmidbauer, N., Semb, A., Stordal, F., and Øystein, H.: Boundary layer ozone depletion as seen in the Norwegian Arctic in spring, J. Atmos. Chem., 23, 301-332, 1996.

Solomon, S., Schmeltekopf, A. L., and Sanders, R. W.: On the interpretation of zenith sky absorption measurements, J. Geophys. Res., 92, 8311-8319, 1987.

Stutz, J. and Platt, U.: Numerical Analyses and Estimation of the Statistical Error of Differential Optical Absorption Spec- troscopy Measurements with Least Square Methods, Appl. Opt., 35, 6041-6053, 1996.

Tuckermann, M., Ackermann, R., Gölz, C., Lorenzen-Schmidt, H., Senne, T., Stutz, J., Trost, B., Unold, W., and Platt, U.: DOAS-observation of halogen radical-catalysed Arctic boundary layer ozone destruction during the ARCTOC-campaigns 1995 and 1996 in Ny-Alesund, Spitsbergen, Tellus, 49B, 533-555, 1997.

Vandaele, A. C., Hermans, C., Simon, P. C., Carleer, M., Colin, R., Fally, S., Mérienne, M.-F., Jenouvrier, A., and Coquart, B.: Measurements of the $\mathrm{NO}_{2}$ Absorption Cross-section from $42000 \mathrm{~cm}$ 1 to $10000 \mathrm{~cm}-1(238-1000 \mathrm{~nm})$ at $220 \mathrm{~K}$ and $294 \mathrm{~K}$, J. Quant. Spectrosc. Radiat. Transfer, 59, 171-184, 1997.

Van Roozendael, M., Fayt, C., Post, P., Hermans, C., and Lambert, J.-C.: Retrieval of $\mathrm{BrO}$ and $\mathrm{NO}_{2}$ from UV-Visible Observations, in: Sounding the troposphere from space: a new era for atmospheric chemistry, Springer-Verlag, ISBN 3-540-40873-8, edited by: Borell, P., Borrell, P. M., Burrows, J. P., and Platt, U., 2003.

von Glasow, R. and Sander, R.: Variation of seasalt aerosol pH with relative humidity, Geophys. Res. Lett., 28, 247-250, 2001.

von Glasow, R., Sander, R., Bott, A., and Crutzen, P. J.: Modeling halogen chemistry in the marine boundary layer. 1 . Cloud-free MBL, J. Geophys. Res., 107, 4341, doi:10.1029/2001JD000942, 2002.

Wagner, T. and Platt, U.: Satellite mapping of enhanced BrO concentrations in the troposphere, Nature, 395, 486-490, 1998.

Wagner, T., Leue, C., Wenig, M., Pfeilsticker, K., and Platt, U.: Spatial and temporal distribution of enhanced boundary layer $\mathrm{BrO}$ concentrations measured by the GOME instrument aboard ERS2, J. Geophys. Res., 106, 24 225-24 236, 2001.

Wagner, T., Dix, B., v. Friedeburg, C., Frieß, U., Sanghavi, S., Sinreich, R., and Platt, U.: MAX-DOAS O4 measurements a new technique to derive information on atmospheric aerosols. (I) Principles and information content, J. Geophys. Res., 109, doi:10.1029/2004JD004904, 2004.

Wagner, T., Burrows, J. P., Deutschmann, T., Dix, B., Hendrick, F., v. Friedeburg, C., Frieß, U., Heue, K.-P., Irie, H., Iwabuchi, H., Kanaya, Y., Keller, J., McLinden, C. A., Oetjen, H., Palazzi, E., Petritoli, A., Platt, U., Postylyakov, O., Pukite, J., Richter, A., van Roozendael, M., Rozanov, A., Rozanov, V., Sinreich, R., Sanghavi, S., and Wittrock, F.: Comparison of Box-AirMass-Factors and Radiances for Multiple-Axis Differential Optical Absorption Spectroscopy (MAX-DOAS) Geometries calculated from different UV/visible Radiative Transfer Models, Atmos. Chem. Phys., 7, 1809-1833, 2007, http://www.atmos-chem-phys.net/7/1809/2007/.

Warren, S.: Optical properties of snow, Rev. Geophys. Space. Phy., 20, 67-89, 1982.

Wittrock, F., Oetjen, H., Richter, A., Fietkau, S., Medeke, T., Rozanov, A., and Burrows, J. P.: MAX-DOAS measurements of atmospheric trace gases in Ny-Ålesund, Atmos. Chem. Phys., 4, 955-966, 2004, http://www.atmos-chem-phys.net/4/955/2004/.

Wilmouth, D. M., Hanisco, T. F., Donahue, N. M., and Anderson, J. G.: Fourier transfor ultraviolet spectroscopy of the $\mathrm{A}_{3 / 2}^{2 \Pi} \leftarrow \mathrm{X}_{3 / 2}^{2 \Pi}$ transition of BrO, J. Phys. Chem. A., 103, 8935-8945, 1999. 